\title{
The Role of Tocotrienol in Preventing Male Osteoporosis-A Review of Current Evidence
}

\author{
Kok-Yong Chin *(-) and Soelaiman Ima-Nirwana \\ Department of Pharmacology, Faculty of Medicine, Universiti Kebangsaan Malaysia, Jalan Yaacob Latif, \\ Bandar Tun Razak, 56000 Cheras, Malaysia; imasoel@ppukm.ukm.edu.my \\ * Correspondence: chinkokyong@ppukm.ukm.edu.my; Tel.: +603-9145-9573
}

Received: 11 February 2019; Accepted: 13 March 2019; Published: 18 March 2019

\begin{abstract}
Male osteoporosis is a significant but undetermined healthcare problem. Men suffer from a higher mortality rate post-fracture than women and they are marginalized in osteoporosis treatment. The current prophylactic agents for osteoporosis are limited. Functional food components such as tocotrienol may be an alternative option for osteoporosis prevention in men. This paper aims to review the current evidence regarding the skeletal effects of tocotrienol in animal models of male osteoporosis and its potential antiosteoporotic mechanism. The efficacy of tocotrienol of various sources (single isoform, palm and annatto vitamin E mixture) had been tested in animal models of bone loss induced by testosterone deficiency (orchidectomy and buserelin), metabolic syndrome, nicotine, alcoholism, and glucocorticoid. The treated animals showed improvements ranging from bone microstructural indices, histomorphometric indices, calcium content, and mechanical strength. The bone-sparing effects of tocotrienol may be exerted through its antioxidant, anti-inflammatory, and mevalonate-suppressive pathways. However, information pertaining to its mechanism of actions is superficial and warrants further studies. As a conclusion, tocotrienol could serve as a functional food component to prevent male osteoporosis, but its application requires validation from a clinical trial in men.
\end{abstract}

Keywords: antioxidant; inflammation; men; mevalonate; osteopenia; skeleton; tocochromanol; vitamin $\mathrm{E}$

\section{Introduction}

Osteoporosis, a metabolic skeletal disease reflected by decreased bone mass, microarchitectural deterioration, and impaired bone strength, affects both men and women. The ultimate consequence of osteoporosis is bone fracture [1]. Women are more susceptible to bone fracture compared to men owing to the difference in bone strength and the presence of menopause in women [2]. However, bone fractures in men, which constitute $29 \%$ of all fragility fractures occurring worldwide, still pose a significant healthcare burden to society [3]. Of the 16.9 billion USD medical cost related to fracture, 4.15 billion USD was contributed by men [4]. Besides, men suffer from greater morbidity and mortality post-fracture compared to women [5,6]. They are also less likely to receive osteoporosis treatment compared women after a bone fracture [7].

Male osteoporosis can be classified into primary and secondary osteoporosis. The cause of primary male osteoporosis is age-related bone loss (senile osteoporosis) or unknown (idiopathic osteoporosis). Secondary male osteoporosis is caused by lifestyles, medical conditions, or medications harmful to the bone. Some of the lifestyle behaviors contributing to male osteoporosis are excessive consumption of alcohol and caffeinated beverages, cigarette-smoking, and physical inactivity. Male osteoporosis can occur secondary to other diseases, such as hypogonadism, gastrointestinal disease, hyperparathyroidism, and thyrotoxicosis. Prolonged use for medications, 
such as glucocorticoids, antineoplastic agents, and anticonvulsants, will also cause osteoporosis [8-10]. The underlying pathology of osteoporosis is imbalanced bone turnover, in which the bone resorption rate (mediated by osteoclasts) exceeds the bone formation rate (mediated by osteoblasts). The reasons for this imbalance vary, but it mainly stems from the disturbance of calcium homeostasis, hormonal changes, chronic inflammation and increased oxidative stress resulted from the risk factors aforementioned [11,12].

The current pharmaceutical interventions for osteoporosis are mainly targeted at postmenopausal women [2]. The currently approved drugs for male osteoporosis include bisphosphonates, teriparatide and denosumab [13]. However, studies revealed that most bone fractures occur in patients with osteopenia rather than those with osteoporosis [14]. The current prophylactic agent for osteoporosis is limited to calcium with or without vitamin D. Thus, functional food components may be a viable option to prevent deterioration of bone health.

Tocotrienol (T3) is one of the functional food components being intensively investigated for its bone-sparing properties [15-17]. T3 and tocopherol (TP) belong to the family of tocochromanol (vitamin E), which is chemically characterized by a chromanol ring and a long carbon tail. Three carbon bonds at the position of 3, 7, 11 on the carbon tail are double bonds for T3, in contrast to single bonds for TP (Figure 1). This property enables T3 to integrate with the lipid bilayer and recycle free radicals better, thus explaining its superior antioxidant effect. T3 also possesses suppressive effects on the mevalonate pathway responsible in cholesterol production, a property not observed with TP. There are four different isoforms of T3, i.e., $\alpha, \beta, \gamma$ and $\delta$-T3, depending on the number and position of the methyl group on the chromanol ring [18]. Natural tocochromanols usually exist in mixtures of varying composition in natural sources, such as botanical oil from palm kernel, annatto seed, rice bran, barley and wheat [19]. $\alpha$-TP is the most abundant vitamin E in food and in the human body after supplementation with palm vitamin E supplementation, followed by $\alpha-\mathrm{T} 3$ [20]. This is related to the binding of tocochromanols on $\alpha$-TP transfer protein, which dictates their bioavailability in the blood [21].

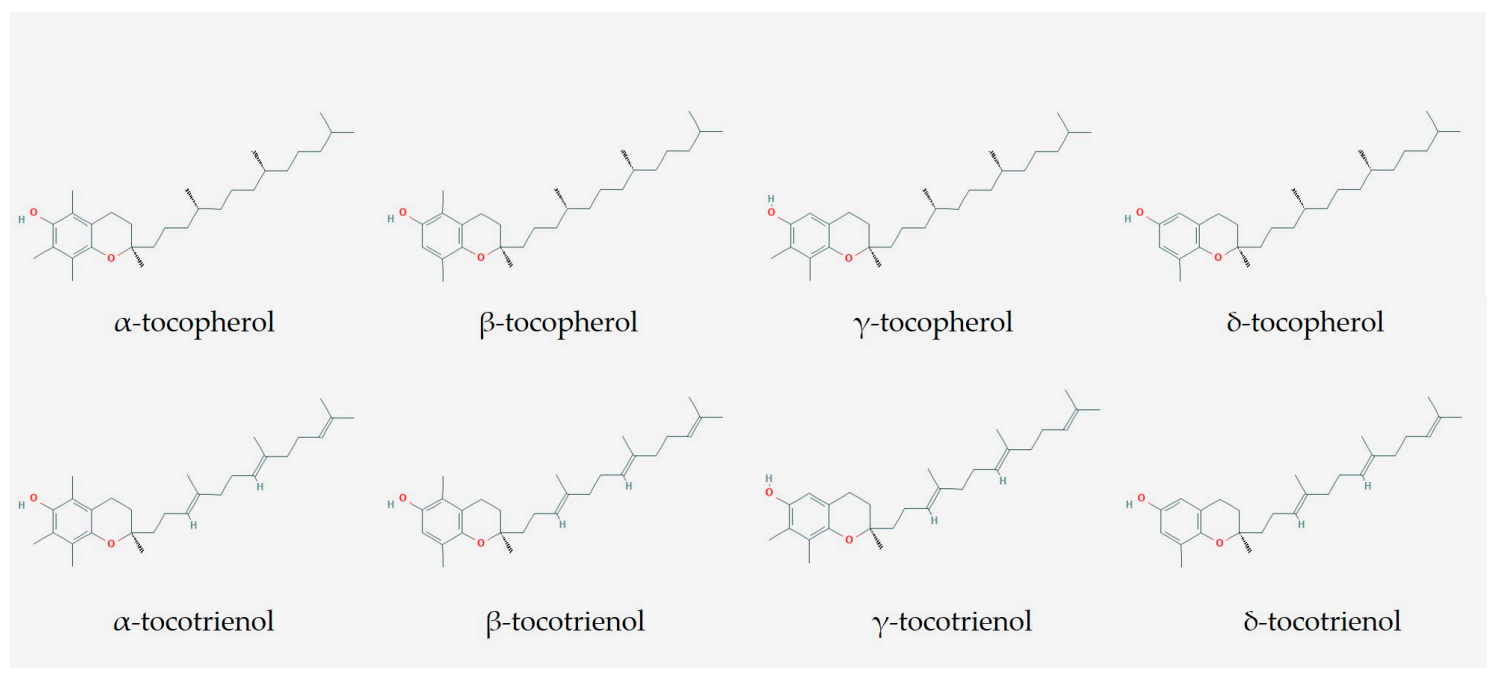

Figure 1. The molecular structure of tocopherol (TF) and tocotrienol (T3). The images are obtained from https:/ / pubchem.ncbi.nlm.nih.gov/.

Several broad reviews on the bone-protective effects of T3 have been published previously $[15,17,22]$. Briefly, T3 showed promising bone-sparing effects on animal models of bone loss due to estrogen deficiency induced by bilateral ovariectomy [23-25]. T3 was able to prevent deterioration of skeletal microarchitecture, mineral density, strength and calcium content [26-28]. The issues on the mechanism of bone protection by T3, whether through decreasing bone resorption or increasing bone formation or both, is still debatable [15]. Recent studies highlighted that T3 also protect male osteoporosis 
models [29,30]. Of note, T3 prevented gonadotropin-releasing hormone agonist $(\mathrm{GnRH})[30,31]$ and metabolic syndrome-induced bone loss [32-34]. In view of the limited options of prophylactic agents for male osteoporosis, T3 may aid in the prevention of bone loss in high-risk men. This review aimed to provide an updated summary of the antiosteoporotic effects of T3 in male osteoporosis. Some of the causes of male osteoporosis will be elaborated further in this review because they are related to the bone loss models used to test T3. Since most of the studies are preclinical, the following discourse will be divided according to the models of bone loss in which the efficacy of T3 has been tested.

\section{The Composition of T3 Used}

The T3 investigated was usually extracted from natural sources, such as palm and annatto oil with varying composition of vitamin E isomers (Table 1). They were called palm vitamin E [33,35-39], palm/annatto T3 [29-32,40,41], T3 enriched fraction [42,43]. In some studies, pure T3 isomers were also used $[42,44,45]$.

Table 1. The composition of tocotrienol (T3) mixture used in experiments

\begin{tabular}{cccccc}
\hline \multirow{2}{*}{ Reference } & \multirow{2}{*}{ Vitamin E Used } & \multicolumn{4}{c}{ Composition of Vitamin E (\%) } \\
\cline { 3 - 5 } & & $\alpha \mathrm{TP}$ & $\boldsymbol{\alpha T 3}$ & $\gamma \mathrm{T3}$ & $\delta \mathrm{T3}$ \\
\hline$[35]$ & Palm vitamin E & 24.4 & 21.6 & 27.7 & 11 \\
{$[36,37]$} & Palm vitamin E & 24.83 & 20.73 & 26.68 & 13.32 \\
{$[38]$} & Palm vitamin E & 22.48 & 23.16 & 36.89 & 12.57 \\
{$[33,39]$} & Palm vitamin E & 21.9 & 24.7 & 36.9 & 12 \\
{$[46]$} & Palm T3 & 18.43 & 14.62 & 32.45 & 23.93 \\
{$[29-32,40,41]$} & Annatto T3 & & & 10 & 90 \\
{$[42,43]$} & Palm T3-enriched fraction & & 43 & 31 & 14 \\
\hline
\end{tabular}

\section{Effects of T3 on Bone Growth}

Peak bone mass in humans is achieved during the third decade of life. A higher peak bone mass is protective against fragility fracture later in life. Apart from genetic factors, physical exercise, nutrition and health conditions may all play a role in determining the individual peak bone mass [47]. Studies were conducted to compare the effects of T3 isomers and $\alpha \mathrm{TP}$ on the skeleton of normal male rats [44,45]. $\gamma \mathrm{T} 3$ (oral, $60 \mathrm{mg} / \mathrm{kg}$ body weight (bw)/day, 4 months) was found to improve the bone structural, cellular and dynamic parameters better than $\alpha$-TP at the same dose in normal male rats [45]. $\gamma \mathrm{T} 3$ also performed better than $\delta \mathrm{T} 3$ (oral, $60 \mathrm{mg} / \mathrm{kg}$ bw/day, 4 months) in improving the cellular and dynamic histomorphometric indices in these rats [44]. Ultimately, rats treated with $\gamma \mathrm{T} 3$ had greater bone strength than those treated with $\alpha \mathrm{TP}$ [45].

On the other hand, an earlier study demonstrated that normal male rats ( 3 months old) treated with palm T3 (oral, $30 \mathrm{mg} / \mathrm{kg}$ bw/day, 8 months) did not change bone mass density (BMD) in any bone sites. However, it reduced the level of serum tartrate acid phosphatase (TRAP), a marker of bone resorption in these animals [35]. Since the dose used in this study was half of the previous studies [44,45], it might not be sufficient to promote growth. In another study, supplementation of high-dose palm T3 (500 mg/ kg diet) for 18 weeks in normal male rats (10 weeks old) also did not alter the bone microstructure, BMD, bone mineral content, mineral apposition and bone formation rate [48]. The study also revealed that expression of genes associated with osteoblast differentiation, number and activity was not significantly altered by high-dose T3 supplementation [48]. The skeletal effects of high-dose T3 and $\alpha$-TP were comparable [48]. The discrepancy in the skeletal effects of high-dose and low-dose T3 supplementation reflected that the bone anabolic effects of T3 diminish at high-dose, indicating a potential U-shaped relationship between bone and vitamin $\mathrm{E}$, which has been hypothesized earlier [49]. At high-dose, T3 was reported to be toxic to bone cells [50].

Another study supplemented normal male rats using palm T3 mixture (oral, $100 \mathrm{mg} / \mathrm{kg}$ bw/day, 4 months) and showed evidence of decreased oxidative stress in the bone, marked by increased 
glutathione peroxidase and decreased lipid peroxidation product (malondialdehyde) [46]. $\alpha \mathrm{TP}$ at the same dose did not change the level of both indicators in the bone [46]. Since free radicals induce osteoclast differentiation and oxidative damage on osteoblasts [51-53], the bone anabolic effects of the T3 could be attributed to its antioxidative activity.

\section{Effects of T3 on Bone Loss Due to Androgen Deficiency (Late-Onset or Drug- Induced Hypogonadism)}

Androgen plays an important role in maintaining the bone health of men [54,55]. During bone growth, androgen is responsible for periosteal apposition in men. Androgen promotes the proliferation and differentiation of pre-osteoblasts [56]. It also enhanced the survival of osteoblasts [57]. Androgen deficiency induced through orchidectomy increases the proliferation of osteoclast and promotes bone resorption through increasing receptor activator of nuclear factor kappa-B ligand (RANKL) synthesis [58]. Androgen can be transformed into estrogen via the aromatase enzyme and part of its skeletal effects are exerted through interaction with estrogen receptors [59]. This is clearly demonstrated by men with dysfunctional estrogen receptors or aromatase who are reported to suffer from severe osteoporosis [60-63].

Elderly men are susceptible to late-onset hypogonadism (LOH) and its complications. LOH is caused by dysregulation of the hypothalamic-gonadal axis, degeneration of the Leydig cells in testes and reduced bioavailability of testosterone due to increased sex-hormone binding globulin (SHBG) in ageing men [64]. However, unlike the menopause in women, testosterone deficiency is not universal in elderly men [65]. Epidemiological studies showed that age-related decline of free and bioavailable testosterone is associated with bone loss [66,67]. Besides, men receiving gonadotropin-releasing hormone $(\mathrm{GnRH})$ agonist (a form of androgen ablation therapy) for prostate cancer are also susceptible to osteoporosis and bone loss [68].

Palm vitamin E mixture rich in T3 (oral, $30 \mathrm{~m} / \mathrm{kg}$ bw/day, 8 months) was shown to prevent the decline in BMD and lumbar calcium content in orchidectomized rats [35]. Compared with rats fed with diet mixed with palm olein, serum alkaline phosphatase (ALP), a bone formation marker of rats supplemented with palm vitamin E was reduced, probably reflecting a reduced bone turnover rate [35]. The efficacy of annatto T3 mixture rich in $\delta$-T3 (oral, $60 \mathrm{mg} / \mathrm{kg}$ bw $/$ day, 8 weeks) was compared with testosterone replacement (intramuscular, $7 \mathrm{mg} / \mathrm{kg}$ weekly, 8 weeks) in orchidectomized rats. Annatto $\mathrm{T} 3$ reduced trabecular separation at the proximal tibia and the distal femur, as well as increased bone volume and trabecular number at the distal femur [29]. It also increased the calcein double-labelled surface of these rats but did not alter mineralizing surface and bone formation rate, indicating the increase in bone formation was marginal [29]. Osteoblast number increased, and osteoclast number was reduced in supplemented orchidectomized rats, but these were not reflected in the bone remodeling markers $[29,40]$. Their serum total calcium level was reduced and tibial calcium content increased [41]. However, this did not translate to an improvement in bone mechanical strength, indicating the changes at the microscopic level and mineral content was not enough to impact bone strength [41]. The authors postulated that given sufficient dose or treatment period, more promising results might be observed [41]. Mechanistically, mRNA expression of markers related to osteoblasts (ALP, collagen I $\alpha 1, \beta$-catenin and osteopontin) was up-regulated prominently but there were no changes in markers related to osteoclasts in this study, showing that the action of annatto T3 may be more anabolic than anti-resorptive [29]. In contrast, the testosterone supplemented group showed significantly better improvement in bone structural parameters, serum bone remodeling markers and bone mechanical strength compared to annatto T3 [29,41]. It should be noted that the dose of testosterone used was supraphysiological, thus partly explaining the more prominent skeletal effects [69].

Buserelin is a GnRH agonist commonly used in androgen ablation therapy [70]. A rat study showed that buserelin (subcutaneous, $75 \mu \mathrm{g} / \mathrm{kg}$ bw / day, 3 months) induced testosterone deficiency and bone loss defined by deterioration in microstructure and strength comparable to, or even worse than, orchidectomy after treatment for three months [71]. The skeletal effects of annatto T3 (oral, 60 and 
$100 \mathrm{mg} / \mathrm{kg} \mathrm{bw} /$ day, 3 months) and calcium supplement (1\% in drinking water) on male rats treated with buserelin had been compared [30,31]. Annatto T3 at both doses increased proximal tibial bone volume and cortical thickness, as well as reduced trabecular separation. It also increased distal femoral bone volume and trabecular thickness $[30,31]$. They also increased osteoblast number without affecting osteoclast number [31]. Besides, both doses lowered serum C-terminal telopeptide of type 1 collagen (CTX-1) level but did not affect the osteocalcin level [31]. Considering the cellular results together, this may reflect that the bone resorption rate was reduced, but the bone formation rate was maintained. Annatto T3 also increased maximum load, stress, and elastic modulus of the bone, but only the dose of $60 \mathrm{mg} / \mathrm{kg}$ increased strain and calcein double-labelled surface [30,31]. The efficacy of annatto T3 was superior to calcium supplementation in many parameters tested.

\section{Effects of T3 on Bone Loss Due to Metabolic Syndrome}

Metabolic syndrome is a collection of five medical conditions, including central obesity, hypertension, hyperglycemia, hypertriglyceridemia, and low high-density lipoprotein cholesterol, which present together, increase the risk of cardiovascular disease and diabetes mellitus exponentially [72]. The relationship between metabolic syndrome and osteoporosis is complicated because some components are harmful to bone health while others are protective [73]. This is reflected in the heterogeneity of the results obtained from previous epidemiological studies, whereby positive, negative and nil relationships between bone health and metabolic syndrome have been reported [74-76]. For instance, obesity is protective against osteoporosis because of mechanical loading and the expression of aromatase enzyme in adipose tissue, which produces estrogen peripherally. At the same time, chronic low-grade inflammation and bone marrow adiposity associated with obesity are detrimental to bone health [77]. Other components, such as increased calcium elimination due to hypertension [78], impaired osteoblast survival and function, as well as increased osteoclast formation due to oxidative stress associated with hyperglycemia [79-81] and oxidized lipoprotein [82-84], have a more straightforward, negative association with bone health. A previous study showed that metabolic syndrome induced by high-carbohydrate high-fat diet decreased bone volume, osteoblast number and osteoid surface but increased eroded surface and serum CTX-1 level in rats [85]. In another study, rats with metabolic syndrome induced by similar diet suffered from reduced tibial bone volume, trabecular number, connectivity density, cortical area, but increased trabecular separation [34]. However, the calcium content of tibial did not alter in these rats [34]. Biomechanically, the tibiae of these rats endured less load but higher strain and displacement [34]. Hence, this animal model is suitable as a bone loss model due to metabolic syndrome.

The rats fed with high-carbohydrate high-fat diet were supplemented with T3 from annatto and palm to assess changes that occurred to the skeletal system [32,33,39]. The supplementation was initiated 8 weeks after the diet was introduced to the rats. Researchers found that annatto T3 at 60 and $100 \mathrm{mg} / \mathrm{kg}$ bw/day for 16 weeks increased femoral bone volume, trabecular number, connectivity density and reduced trabecular separation and structural model index as assessed using micro-computed tomography [32]. Annatto T3 at both doses also increased osteoblast number and mineral apposition rate at the femur, implying that it could be anabolic to the bone [32]. Only annatto $\mathrm{T} 3$ at $100 \mathrm{mg} / \mathrm{kg}$ bw raised the load and Young's modulus of the femur [32]. Another study used palm T3 at similar doses and showed that it prevented the decline in bone volume and trabecular number, as well as reducing structural model index and trabecular separation of the rats' femurs [33]. Palm T3 at both doses also elevate load and Young's modulus of the femur, but only the dose of $60 \mathrm{mg} / \mathrm{kg} \mathrm{bw}$ improved femoral stiffness [33]. Similarly, palm T3 might be anabolic because it enhanced osteoblast surface and osteoid surface on the trabecular bone, but this was not reflected in the bone remodeling markers [39]. Both annatto T3 and palm T3 lowered the interleukin- $1 \alpha$ and interleukin-6 [32,39]. 


\section{Effects of T3 on Bone Loss Due to Cigarette-Smoking}

Cigarette-smoking is recognized as an independent risk factor for bone loss and fracture [86,87]. In vitro studies showed that one of the major components of cigarette smoke, nicotine, decreased the formation of osteoblasts from human bone marrow mesenchymal stem cells [88]. Another study demonstrated that proliferation and formation of mineralized nodules were reduced in rat primary osteoblasts [89]. Gene expression analysis on these cells revealed two pathways related to bone metabolism affected by nicotine, i.e., Hedgehog and Notch pathways [89]. Other studies found that the effects of nicotine on osteogenesis might be bi-phasic in nature, whereby negative impacts were only observed with high doses [90]. Rats exposed to nicotine (intraperitoneal, $7 \mathrm{mg} / \mathrm{kg} / 6$ days a week, 4 months) showed decreased bone volume and trabecular number, bone mineralization and formation rate [91]. This might be contributed by increased bone resorption as shown through higher osteoclast number and eroded surface on the trabecular bone in the nicotine-treated rats compared to control [91]. The higher bone resorption was mediated by increased expression of proinflammatory cytokines, such as interleukin-1 and interleukin-6 [91]. The adverse effects of smoking on bone cannot be easily reversed even after cessation. This is illustrated by another animal, whereby the skeletal negative impacts of nicotine (intraperitoneal, $7 \mathrm{mg} / \mathrm{kg} / 6$ days a week, 2 months) could not be reversed after cessation for two months [92]. Changes in bone remodeling could be observed as early as 2 months, indicated by increased bone resorption marker (serum osteocalcin) and decreased bone resorption marker (serum pyridinoline), and they persisted after cessation [92].

Comparison of the effects of palm T3-enriched fraction, $\gamma$-T3 and $\alpha$-TP in reversing bone damage due to exposure to nicotine has been attempted in male rats [42]. All treatment groups demonstrated improved bone volume, bone formation and reduction in osteoclast surface [42]. Groups treated with T3 experienced additional improvement in trabecular thickness, osteoblast number and eroded surface [42]. The mineralization rate and bone formation rate of rats receiving $\gamma$-T3 were higher compared to those receiving T3-enriched fraction and $\alpha$-TP [42]. Further studies showed that T3-enriched fraction and $\gamma$-T3 prevented nicotine-induced interleukin- 1 and interleukin-6, as well as halting the increase in serum pyridinoline [43]. Serum osteocalcin was also increased with both treatments [43]. These changes were not seen with $\alpha$-TP treatment [43]. A gene expression study showed that palm vitamin E (oral, $60 \mathrm{mg} / \mathrm{kg} /$ day, 2 months) rescued suppression of RUNX2, OSX and BMP-2 mRNA expression in the femur of rats post-nicotine administration (intraperitoneal, $7 \mathrm{mg} / \mathrm{kg} /$ 6 days a week, 2 months) in male rats [93].

\section{Effects of T3 on Bone Loss Due to Alcohol}

Epidemiological studies have shown that light alcohol intake may be beneficial to the bone but heavy alcohol use is associated with bone loss in men [94]. The mechanism of alcohol-induced bone loss is complex [95]. Male alcohol abusers were reported to have a lower testosterone level and higher oxidative stress compared to healthy control [96]. Chronic alcohol use also increases the production of proinflammatory cytokines, such as tumor necrosis factor- $\alpha$ and interleukin- $1 \beta$, which will impair bone formation [97]. Besides, high-dose alcohol was found to regulate mammalian target of rapamycin (mTOR) pathway and reduce osteoblast and bone formation (indicated by reduced runt-related factor-2 (RUNX2) and ALP expression) and increase adipocyte formation (indicated by increased peroxisome proliferator-activated receptor- $\gamma$ expression) in the bone marrow [98]. Serum sclerostin level was reported to increase in alcoholic patients, and it correlated negatively with serum osteocalcin (a bone formation marker) and positively with telopeptide (a bone resorption marker) [99]. Other bone related pathways that may be impacted by chronic alcohol use include vitamin D-parathyroid (PTH) axis and insulin-like growth factor-1 (IGF1) - growth hormone (GH) signaling [95].

A previous study compared the bone-sparing effects of palm vitamin E and $\alpha$-TP (oral, $60 \mathrm{mg} / \mathrm{kg}$ $\mathrm{bw} /$ day, 2 months after the last alcohol ingestion) in a binge-drinking male rat model (oral, $3 \mathrm{~g} / \mathrm{kg}$ bw 20\% ethanol in saline, 3 days a week for 4 weeks). Both palm vitamin $\mathrm{E}$ and $\alpha$-TP increased tibial calcium and magnesium compared to the vehicle-treated group. Palm vitamin E but not $\alpha$-TP was 
shown to improve the biomechanical strength of the tibiae as evidenced by increased maximum force, ultimate stress and Young's modulus values. However, the authors did not investigate the mechanism of action of palm vitamin $\mathrm{E}$ in reducing the skeletal damage of alcohol but suggested the antioxidative and anti-inflammatory properties of T3 might play a role [38].

\section{Effects of T3 on Bone Loss Due to Glucocorticoid}

Long-term glucocorticoid use is a major risk factor of osteoporosis. Glucocorticoid mainly affects bone formation, whereby it impairs the differentiation and function of osteoblasts [100]. High-dose glucocorticoid reduces the expression of Wnt and increases the expression of Wnt inhibitors secreted frizzled-related protein and dickkopf-related protein 1 (DKK1) in mature osteoblasts [101]. It also increases serum sclerostin level that correlates negatively with bone formation markers [102]. Glucocorticoid activates glycogen synthase kinase- $3 \beta$ in the Wnt-signaling pathway, thereby increases the phosphorylation of $\beta$-catenin by GSK-3 and inhibits nuclear translocation of $\beta$-catenin [103]. It also antagonizes Runx2 signaling and reduces the expression of several genes related to osteoblastogenesis [104]. The effects of glucocorticoid on osteoclastogenesis are mainly a derivative of decreased osteoprotegerin (OPG) production by osteocytes, which promotes osteoclastogenesis [105]. Indirectly, glucocorticoid reduces blood testosterone level and calcium absorption, as well as altering IGF-1-GH axis, which altogether cause bone loss [106-108].

The effects of $\mathrm{T} 3$ in preventing bone loss due to glucocorticoid have been explored in a few studies. Male rats were adrenalectomized and supplemented with dexamethasone to mimic glucocorticoid replacement therapy in human post-adrenalectomy. $\gamma$-T3 (oral, $60 \mathrm{mg} / \mathrm{kg}$ bw/day for 8 weeks) was shown to preserve bone lumbar calcium content in rats given low (intramuscular, $120 \mathrm{mg} / \mathrm{kg} / \mathrm{bw}$ ) and high-dose dexamethasone (intramuscular, $240 \mathrm{mg} / \mathrm{kg} / \mathrm{bw}$ ), although it did not affect the BMD of the rats [37]. It also prevented the dexamethasone-induced increase in fat mass assessed by DXA. $\alpha$-TP at the same dose did not demonstrate similar effects in the same study [37]. In another study, dexamethasone (intramuscular, $120 \mathrm{mg} / \mathrm{kg} / \mathrm{bw}$ ) reduced BMD gained in 8 weeks, femoral length and calcium content [36]. Palm vitamin E (oral, $60 \mathrm{mg} / \mathrm{kg}$ bw / day for 8 weeks) prevented all these changes [36].

A summary of the bone-sparing properties of $\mathrm{T} 3$ is presented in Table 2. 
Table 2. Skeletal properties affected by tocotrienol (T3).

\begin{tabular}{|c|c|c|c|c|c|c|c|c|c|c|c|c|c|c|c|c|c|c|c|c|c|c|c|}
\hline & & & & \multicolumn{20}{|c|}{ Skeletal Properties Affected by T3 } \\
\hline Ref & $\begin{array}{l}\text { Induction of } \\
\text { Bone Loss }\end{array}$ & Treatment & Period & $\sum_{\infty}^{B}$ & $\begin{array}{l}Z \\
\dot{0} \\
\dot{R}\end{array}$ & $\begin{array}{l}\vec{E} \\
\stackrel{H}{H}\end{array}$ & $\begin{array}{l}\text { की } \\
\text { ही }\end{array}$ & $\sum_{\infty}$ & 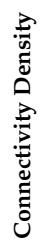 & 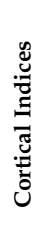 & $\begin{array}{l}n \\
0 \\
0 \\
0 \\
z \\
z \\
0 \\
0\end{array}$ & $\begin{array}{l}n \\
0 \\
0 \\
0 \\
z \\
0 \\
0\end{array}$ & 黛 & $\begin{array}{l}\text { 邑 } \\
\text { की }\end{array}$ & $\frac{\vec{c}}{a}$ & 总 & 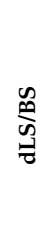 & $\sum_{\Sigma}^{\infty}$ & $\underset{\Sigma}{\tilde{\Sigma}}$ & $\sum_{\substack{\infty \\
\infty}}^{\infty}$ & $\sum_{i}^{\rho}$ & 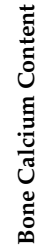 & 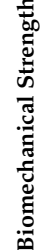 \\
\hline
\end{tabular}

\begin{tabular}{|c|c|c|c|c|c|c|c|c|c|c|c|c|c|c|c|c|c|c|c|c|c|c|c|}
\hline [29] & Orchidectomy & $\begin{array}{c}\mathrm{AnT} 3 \\
60 \mathrm{mg} / \mathrm{kg}\end{array}$ & 2 months & $\uparrow$ & $\uparrow$ & $\leftrightarrow$ & $\downarrow$ & $\leftrightarrow$ & $\leftrightarrow$ & & & & & & & $\downarrow$ & $\uparrow$ & $\leftrightarrow$ & $\leftrightarrow$ & $\leftrightarrow$ & & & \\
\hline [40] & Orchidectomy & $\begin{array}{c}\mathrm{AnT3} \\
60 \mathrm{mg} / \mathrm{kg}\end{array}$ & 2 months & & & & & & & & $\uparrow$ & $\downarrow$ & $\downarrow$ & $\uparrow$ & $\uparrow$ & & & & & & & & \\
\hline [41] & Orchidectomy & $\begin{array}{c}\mathrm{AnT3} \\
60 \mathrm{mg} / \mathrm{kg}\end{array}$ & 2 months & & & & & & & & & & & & & & & & & & & $\begin{array}{c}\uparrow \\
\text { (tibia) }\end{array}$ & $\leftrightarrow$ \\
\hline [35] & Orchidectomy & $\begin{array}{c}\text { PVE } \\
30 \mathrm{mg} / \mathrm{kg} \\
\end{array}$ & 8 months & & & & & & & & & & & & & & & & & & $\uparrow$ & $\begin{array}{c}\uparrow \\
\text { (lumbar) }\end{array}$ & \\
\hline [30] & $\begin{array}{c}\text { Chemical castration } \\
\text { by buserelin }\end{array}$ & $\begin{array}{l}\text { AnT3 } 60 \text { or } \\
100 \mathrm{mg} / \mathrm{kg}\end{array}$ & 3 months & $\uparrow$ & $\uparrow$ & $\leftrightarrow$ & $\downarrow$ & $\leftrightarrow$ & $\uparrow$ & $\begin{array}{c}\uparrow \\
\text { thickness } \\
\end{array}$ & & & & & & & & & & & & $\begin{array}{c}\uparrow \\
\text { (femur) }\end{array}$ & $\uparrow$ \\
\hline [31] & $\begin{array}{c}\text { Chemical castration } \\
\text { by buserelin }\end{array}$ & $\begin{array}{l}\text { AnT3 } 60 \text { or } \\
100 \mathrm{mg} / \mathrm{kg}\end{array}$ & 3 months & $\uparrow$ & $\leftrightarrow$ & $\uparrow$ & $\leftrightarrow$ & & & & & $\downarrow$ & $\leftrightarrow$ & $\leftrightarrow$ & $\leftrightarrow$ & $\downarrow$ & $\begin{array}{c}\uparrow \\
(60 \mathrm{mg} / \mathrm{kg} \text { only }) \\
\end{array}$ & $\leftrightarrow$ & $\leftrightarrow$ & $\leftrightarrow$ & & & \\
\hline [32] & Metabolic syndrome & $\begin{array}{l}\text { AnT3 60 or } \\
100 \mathrm{mg} / \mathrm{kg}\end{array}$ & 4 months & $\uparrow$ & $\uparrow$ & $\leftrightarrow$ & $\downarrow$ & $\downarrow$ & $\uparrow$ & $\leftrightarrow$ & $\uparrow$ & $\leftrightarrow$ & $\leftrightarrow$ & $\leftrightarrow$ & $\leftrightarrow$ & $\begin{array}{c}\uparrow \\
(60 \mathrm{mg} / \mathrm{kg}) \\
\end{array}$ & $\leftrightarrow$ & $\leftrightarrow$ & $\begin{array}{c}\uparrow \\
(60 \mathrm{mg} / \mathrm{kg} \text { only }) \\
\end{array}$ & $\leftrightarrow$ & & $\begin{array}{c}\leftrightarrow \\
\text { (femoral) }\end{array}$ & $\uparrow$ \\
\hline [33] & Metabolic syndrome & $\begin{array}{c}\text { Palm T3 } 60 \text { or } \\
100 \mathrm{mg} / \mathrm{kg}\end{array}$ & 4 months & $\uparrow$ & $\uparrow$ & $\leftrightarrow$ & $\downarrow$ & $\downarrow$ & $\leftrightarrow$ & $\leftrightarrow$ & & & & & & & & & & & & $\begin{array}{c}\leftrightarrow \leftrightarrow \\
\text { (femoral) }\end{array}$ & $\uparrow$ \\
\hline [39] & Metabolic syndrome & $\begin{array}{c}\text { Palm T3 } 60 \text { or } \\
100 \mathrm{mg} / \mathrm{kg}\end{array}$ & 4 months & $\uparrow$ & $\leftrightarrow$ & $\leftrightarrow$ & $\leftrightarrow$ & & & & $\uparrow$ & $\leftrightarrow$ & $\begin{array}{c}\downarrow \\
(100 \mathrm{mg} / \mathrm{kg}) \\
\end{array}$ & $\uparrow$ & $\leftrightarrow$ & $\begin{array}{c}\downarrow \\
(60 \mathrm{mg} / \mathrm{kg}) \\
\end{array}$ & $\leftrightarrow$ & $\leftrightarrow$ & $\leftrightarrow$ & $\leftrightarrow$ & $\leftrightarrow$ & & \\
\hline [37] & Glucocorticoid & $\begin{array}{c}\gamma-\mathrm{T} 3 \\
60 \mathrm{mg} / \mathrm{kg} \\
\end{array}$ & 2 months & & & & & & & & & & & & & & & & & & $\leftrightarrow$ & $\begin{array}{c}\uparrow \\
\text { (lumbar) }\end{array}$ & \\
\hline [36] & Glucocorticoid & $\begin{array}{c}\text { PVE } \\
60 \mathrm{mg} / \mathrm{kg} \\
\end{array}$ & 2 months & & & & & & & & & & & & & & & & & & $\uparrow$ & $\begin{array}{c}\uparrow \\
\text { (femoral) } \\
\end{array}$ & \\
\hline [42] & Nicotine & $\begin{array}{c}\text { Palm T3 } \\
\text { enriched } \\
\text { fraction, } \gamma \text {-T3 } \\
60 \mathrm{mg} / \mathrm{kg}\end{array}$ & 2 months & $\uparrow$ & $\leftrightarrow$ & $\uparrow$ & & & & & $\uparrow$ & $\downarrow$ & $\downarrow$ & & & $\downarrow$ & & & $\uparrow$ & $\uparrow$ & & & \\
\hline [38] & Alcohol & $\begin{array}{c}\text { PVE } \\
60 \mathrm{mg} / \mathrm{kg}\end{array}$ & 2 months & & & & & & & & & & & & & & & & & & & $\begin{array}{c}\uparrow \\
\text { (tibial) }\end{array}$ & $\uparrow$ \\
\hline
\end{tabular}

Abbreviation: BV/TV, bone volume; Tb.N, trabecular number; Tb.Th, trabecular thickness; Tb.Sp, trabecular separation; SMI, structural model index; Ob.N. or Ob.S, osteoblast number or surface; Oc.N or Oc.S, osteoclast number or surface; ES/BS, eroded surface; OS/BS, osteoid surface; OV/BV, osteoid volume; sLS/BS, single-labelled surface; dLS/BS, double-labelled surface; MS, mineralizing surface; MAR, mineral apposition rate; BFS/MS, bone formation rate; BMD, bone mineral density; AnT3, annatto tocotrienol; PVE, palm vitamin

$\mathrm{E} ; \uparrow$, increase/improve; $\downarrow$ reduce; $\leftrightarrow$ no change. 


\section{Mechanism of Action of T3 in Protecting Bone Health}

\subsection{Oxidative Stress}

The role of oxidative stress in bone remodeling has been established in preclinical studies. Free radical species, especially hydrogen peroxide, facilitate intracellular signaling in pre-osteoclasts and promote their differentiation into mature osteoclasts and bone resorption activity through nuclear factor- $\mathrm{kB}$ (NF- $\mathrm{kB}$ ) and mitogen-activated protein kinase (MAPK) pathways [51]. Oxidative stress also decreases the survival of osteoblasts and osteocytes, encourages their apoptosis and diminishes bone formation [109]. However, the relationship between oxidative stress and bone is complicated in vivo. Smoking [110], alcohol drinking [111] and metabolic syndrome [112] are contributors to oxidative stress in vivo regardless of sex. Estrogen is regarded as an antioxidant and postmenopausal osteoporosis is suggested to be partly attributable to increased oxidative stress [113]. On the other hand, the role of androgen on oxidative stress is controversial, whereby some studies reported a protective role of androgen against oxidative stress [114-116] while others demonstrated that androgen further enhanced oxidative stress in various systems [117-119]. Currently, the contribution of oxidative stress in bone loss due to androgen deficiency is uncertain.

In vitro studies showed that oxidative stress induced by hydrogen peroxide on primary osteoblasts overwhelmed their antioxidative enzyme defense. This subsequently promotes the apoptosis of these osteoblasts. $\gamma-\mathrm{T} 3$ prevented the decrease in the activity of antioxidative enzymes and apoptosis of osteoblasts [120]. However, high-dose $\gamma$-T3 was demonstrated to be cytotoxic to osteoblasts $[50,120]$. In contrast, $\alpha$-TP did not prevent the apoptotic effects of hydrogen peroxide in osteoblasts [50]. It is not known whether T3 achieved its protective activities by acting as a free radical scavenging agent or by regulating the NF-E2-related factor 2 (NRF2)-associated antioxidant responsive element in the cells. A previous study demonstrated that $\gamma$-T3 was able to stabilize the expression of NRF2 in keratinocytes and promoted the mRNA expression of heme oxygenase- 1 and $\mathrm{NAD}(\mathrm{P}) \mathrm{H}$ :quinone oxidoreductase-1 [121]. Hence, the mechanism of antioxidant action on T3 in protecting bone cells against oxidative damage should be examined further.

\subsection{Inflammation}

The NF- $\mathrm{kB}$ pathway plays a very significant role in bone remodeling. It is a family of transcription factors involved in inflammatory and immune response [122]. The pathway can be divided into canonical and non-canonical. In the canonical pathway, IKB kinase (IKK), upon activation by stimuli, will phosphorylate IKB $\alpha$ and subject it to degradation, subsequently enable nuclear translocation of NF- $\mathrm{KB}$ [122]. Activation of NF- $\mathrm{KB}$ pathway leads to transcription of genes related to inflammation, including cytokines, cell adhesion molecules and chemokines [123]. IKK $\beta$ (a component of IKK) is critical in the survival and differentiation of osteoclast progenitors [124]. It prevented apoptosis of osteoclast progenitors induced by Jun N-terminal kinase (JNK) activation [124]. Deletion of IKK $\beta$ caused osteopetrosis in mice due to defective osteoclast formation [125]. IKK $\beta$ also rescued the osteoclast progenitors from tumor necrosis factor (TNF) $\alpha$-induced apoptosis [125]. Deletion of IKK $\beta$ also prevented endotoxin-induced inflammatory bone loss in mice [125]. Activation of the non-canonical pathway promotes TNF-induced osteoclast formation through increased RelB. Inhibition of TNF receptor-associated receptor (TRAF) 3 and p100 also reduced osteoclastogenesis [126,127]. With regards to bone formation, inhibition of NF-KB through IKK mutation stimulates osteoblast function but not its differentiation [128]. Ovariectomized mice with mutated IKK were protected against bone loss. These effects were mediated through up-regulation of JNK/Fra-1 pathway [128]. The regulation of NF- $\mathrm{kB}$ by various stimuli would explain the pathogenesis of bone loss secondary to inflammatory diseases.

T3 could suppress the activation of NFKB pathway, as evidenced from previous studies using cancer cells or macrophages [129-131]. Particularly, $\gamma$-T3 and $\delta$-T3 suppressed NF- $\mathrm{KB}$ activity better than other T3 isomers in a study using pancreatic cells [132]. T3 inhibited IKK activation, 
phosphorylation and degradation of IKB $\alpha$ and prevented nuclear translocation of NF- $\mathrm{KB}[130,131,133]$. $\gamma$-T3 was shown to block NF-KB reporter gene transcription induced by TNF, TRAF2 and NF-KB-inducing kinase. This demonstrated that T3 can block the non-canonical pathway [133]. T3 was shown to lower inflammatory cytokines levels in an animal model of osteoporosis induced by metabolic syndrome [32,33], nicotine [43] and ferric nitrilotriacetate [134]. However, there is no direct evidence demonstrating the suppression of NF- $\mathrm{KB}$ pathway by T3 in bone cells. The closest evidence is the suppression of LPS-induced IKB $\alpha$ in the bone marrow-derived macrophages, which could serve as precursors to osteoclasts, by $\gamma$-T3 [130]. This could explain the inhibitory effects of $\gamma$-T3 on osteoclast formation from bone marrow macrophages in a separate study [135].

\subsection{Mevalonate Pathway}

The mevalonate pathway, known to be responsible for cholesterol synthesis, also produces isoprenoids involved in prenylation of signaling proteins, known as GTPases [136]. These proteins are known to regulate bone remodeling [137]. For instance, PTH-induced osteoblastogenesis was shown to be mediated by suppression of the mevalonate pathway and Rho-associated protein kinase inhibition [138]. Osteoclast functions, including the formation of ruffled border and sealing zone, depend on RhoA, Rac, Cdc42, RhoU, and Arf6. Ras regulates the survival of osteoclasts [139]. Nitrogen-containing bisphosphonates, a class of antiosteoporosis agents, exert their functions by inhibiting farnesyl-diphosphate synthase [140]. Statins, a class of cholesterol-lowering agents, inhibits 3-hydroxy-3-methyl-glutaryl-CoA reductase (HMGR), the rate-determining enzyme of the mevalonate pathway to achieve its therapeutic effects [141]. Although statins are not used in the treatment of osteoporosis, its prolonged consumption has been associated with increased hip and lumbar BMD and reduced hip fracture risk in humans [142]. Several preclinical studies have established that T3 is a potent suppressor of the mevalonate pathway. T3 was shown to decrease the protein expression of HMGR post-transcriptionally by increasing its degradation rate in hepatocytes [143]. This was echoed by studies using cancer cells, demonstrating down-regulation of HMGR expression by T3, which partially explains its anticancer activities [144-146]. As a result, of HMGR suppression, metabolites along the mevalonate pathway, such as farnesyl-diphosphate, squalene and cholesterol were reduced [147].

The involvement of mevalonate pathway in the bone-sparing effects of $\mathrm{T} 3$ has been implied in several studies. Studies in ovariectomized rats showed that supplementation of annatto T3 in combination with lovastatin prevented bone loss better than individual treatments, as evaluated through bone histomorphometry, bone calcium content and bone strength [26-28]. The combination therapy also enhanced the mRNA expression of BMP-2 in the femur of the rats better than annatto T3 or lovastatin alone [28]. In an ovariectomized mice model, daily supplementation of mevalonate (oral, $25 \mathrm{mg} / \mathrm{kg}$ bw, daily for three months) diminished the bone-protective effects of $\gamma$-T3 (intraperitoneal, $100 \mathrm{mg} / \mathrm{kg}$ bw, once monthly for three months) as evaluated by bone structural and histomorphometric indices [148]. Mevalonate also suppressed $\gamma$-T3 induced elevation of transcription factors mRNA expression for osteoblastogenesis, such as osterix and RUNX2. Up-regulation of OPG mRNA and down-regulation of RANKL mRNA by $\gamma$-T3 in mice was abolished by mevalonate co-treatment [148]. The observation was validated in an in vitro study using bone marrow cells and UAMS-32P cells. Treatment with $\gamma$-T3 significantly reduced the intracellular farnesyl pyrophosphate and geranylgeranyl pyrophosphate level, both of which are intermediates in the mevalonate pathway. $\gamma$-T3 mediated suppression of osteoclast-like cell formation stimulated by parathyroid was also abrogated by mevalonate [148].

A summary of the suggested mechanism of actions of $\mathrm{T} 3$ in preventing bone loss is presented in Figure 2. 


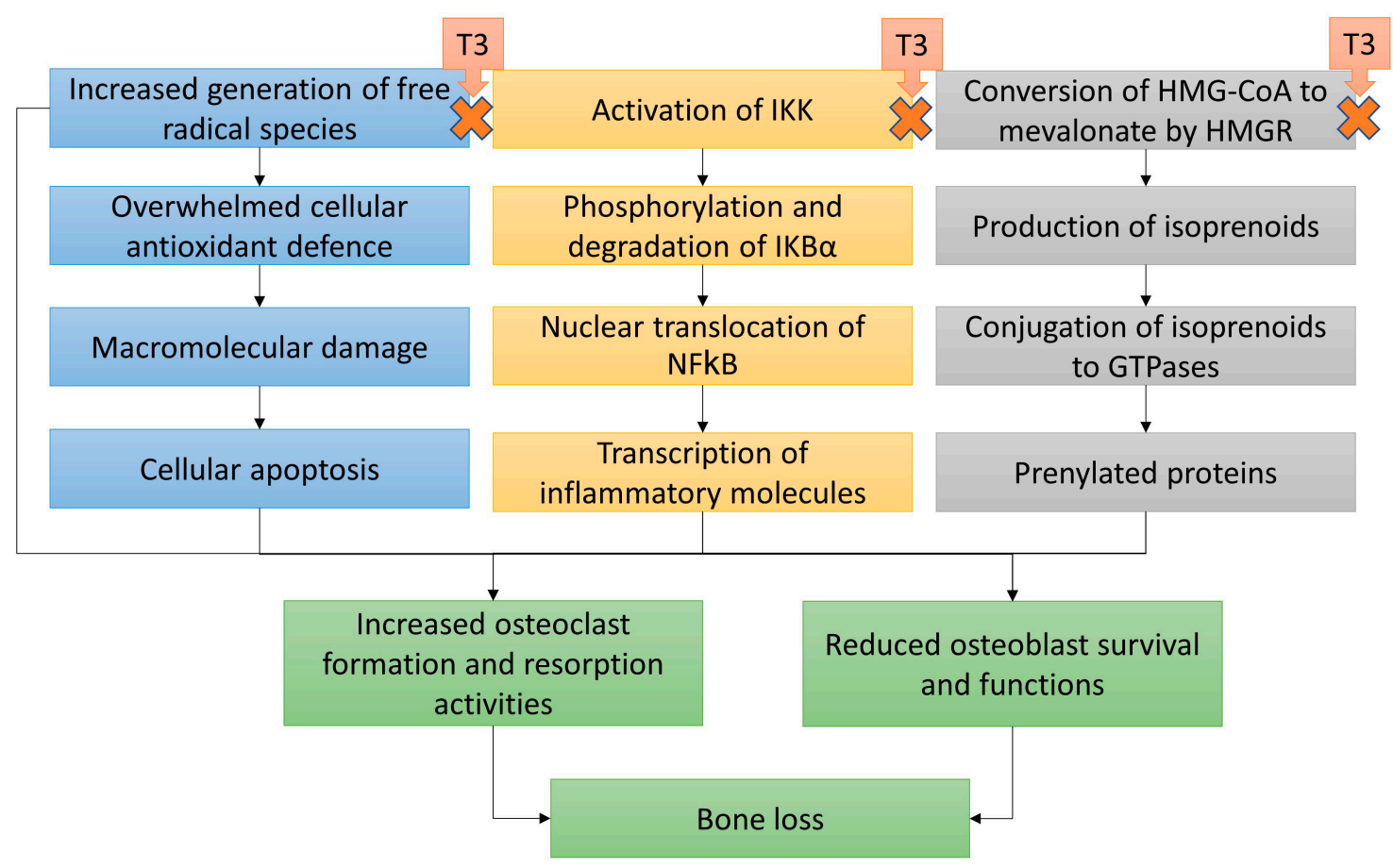

Figure 2. The proposed mechanism of action of tocotrienol (T3) in protecting bone health. Abbreviation: HMG-CoA, 3-hydroxy-3-methylglutaryl-CoA; HMGR, 3-hydroxy-3-methylglutaryl-CoA reductase; IKB, nuclear factor of kappa light polypeptide gene enhancer in B-cells inhibitor, alpha; IKK, IKB kinase; NF- $\mathrm{B}$, nuclear factor kappa-light-chain-enhancer of activated B-cells.

\section{Perspectives on the Use of $\mathrm{T} 3$}

Three major concerns on the application of T3 as a bone-sparing agent are its safety, bioavailability, and marketability. In terms of safety, one study in postmenopausal women with osteopenia revealed that annatto T3 at $600 \mathrm{mg}$ for 12 weeks did not affect their liver and kidney functions [149]. It also suppressed the high turnover markers among the subjects, indicated by reduced serum bone ALP and urinary N-terminal telopeptide. This was accompanied by a reduced level of 8-hydroxy2'-deoxyguanosine, an oxidative stress marker [150]. However, similar studies on the use of T3 for bone protection in men is absent. Toxicity studies in female mice revealed increased bleeding risk with high-dose palm vitamin E (oral, 500 and $1000 \mathrm{mg} / \mathrm{kg}$ for 14 and 42 days) [151], but this dose was much higher than the desired dose for bone strengthening effects. Similar toxicity studies in male animals or men were limited.

In terms of bioavailability, T3 generally showed much lower bioavailability compared to $\alpha$-TP due to the competitive binding at $\alpha$-TP transport protein, which regulates the circulating vitamin $\mathrm{E}$ level [21]. However, a previous study established that a single-dose of emulsified $\gamma$-T3 was deposited in the rat femur and spine 14 days after supplementation [152]. The treatment also exerts biological effects on the bone, by up-regulating OPG mRNA and down-regulating RANKL mRNA [152]. Various means to increase the bioavailability of $\mathrm{T} 3$ are being studied, including the use of the self-emulsifying system [153] and nanoparticles [154].

There are some commercial challenges in developing T3 as a pharmaceutical product to prevent osteoporosis in men. A patent search revealed two relevant patents pertaining to the use of T3 as an antiosteoporotic agent $[155,156]$. However, the T3 supplements are prevalent in the market, and natural composition is usually used. It might hamper the interest of pharmaceutical companies to invest and develop it as pharmaceutical products. However, it still has great potential to be developed into functional foods and nutraceuticals for men to halt bone loss. In addition, T3 also showed beneficial effects against other age-related diseases, such as metabolic syndrome $[157,158]$, neurogenerative 
disease [159], arthritis [160,161], sarcopenia [162,163], which may be attractive to elderly men suffering from multiple conditions concurrently.

\section{Limitations}

This review is not without its limitations. The ultimate consequence of male osteoporosis is fragility fracture, which carries significant morbidity and mortality to the patients. Fragility fracture is not only predicted by reduced bone mass, but also muscle and cognitive functions of an individual, which are related to the gait and tendency to fall [164]. This review has only addressed the effects of T3 on bone mass, structure, and strength, but not on evidence for muscle and cognitive functions. However, osteoporosis remains the most treatable predictors of fracture, and it can be prevented by T3 supplementation.

\section{Conclusions}

As a conclusion, evidence accumulated thus far has demonstrated promising effects of T3 as a preventive agent against male osteoporosis in models of bone loss induced by testosterone deficiency (surgical or chemical ablation), metabolic syndrome, cigarette-smoking, glucocorticoids and alcoholism. Men with these risk factors or osteopenia could benefit from T3 supplementation to stop the progression of bone loss. The human equivalent dose of T3 proven to prevent osteoporosis is approximately $600 \mathrm{mg} /$ day, to be taken after meals to enhance absorption. However, there is no clinical trial to study the skeletal effects of T3 in men so far. Thus, the efficacy of T3 in preventing the progression of male osteoporosis still awaits new clinical evidence in humans. The bone-sparing effects of T3 could be mediated by its antioxidant, anti-inflammatory, and mevalonate-suppressive effects. However, more studies are needed to illustrate its mechanism of actions, especially the cell signaling pathways involved.

Author Contributions: K.-Y.C. drafted the manuscript. S.I.-N. provided critical review for the manuscript.

Funding: The authors are funded by Ministry of Education, Malaysia through grant FRGS/1/2018/SKK10/ UKM/03/1 and Universiti Kebangsaan Malaysia through grant GUP-2017-060.

Acknowledgments: We thank Ministry of Education, Malaysia and Universiti Kebangsaan Malaysia for funding the studies through grant FRGS/1/2018/SKK10/UKM/03/1 and GUP-2017-060.

Conflicts of Interest: The authors declare no conflict of interest.

\section{References}

1. Edwards, M.H.; Dennison, E.M.; Aihie Sayer, A.; Fielding, R.; Cooper, C. Osteoporosis and sarcopenia in older age. Bone 2015, 80, 126-130. [CrossRef] [PubMed]

2. Cawthon, P.M. Gender differences in osteoporosis and fractures. Clin. Orthop. Relat. Res. 2011, 469, 1900-1905. [CrossRef] [PubMed]

3. Johnell, O.; Kanis, J. An estimate of the worldwide prevalence and disability associated with osteoporotic fractures. Osteoporos. Int. 2006, 17, 1726-1733. [CrossRef] [PubMed]

4. Burge, R.; Dawson-Hughes, B.; Solomon, D.H.; Wong, J.B.; King, A.; Tosteson, A. Incidence and economic burden of osteoporosis-related fractures in the united states, 2005-2025. J. Bone Miner. Res. 2007, 22, 465-475. [CrossRef] [PubMed]

5. Chatterton, B.D.; Moores, T.S.; Ahmad, S.; Cattell, A.; Roberts, P.J. Cause of death and factors associated with early in-hospital mortality after hip fracture. Bone Jt. J. 2015, 97-B, 246-251. [CrossRef] [PubMed]

6. Mizrahi, E.H.; Arad, M.; Fleissig, Y.; Adunsky, A. Gender differences in functional outcome of elderly hip fracture patients. Geriatr. Gerontol. Int. 2014, 14, 845-850. [CrossRef]

7. Wang, C.C.; Wu, C.H.; Farley, J.F. Patterns of pharmacological treatment for osteoporosis among patients qualified for pharmacotherapy according to the national osteoporosis foundation guidelines. Ann. Pharmacother. 2015, 49, 995-1003. [CrossRef]

8. Willson, T.; Nelson, S.D.; Newbold, J.; Nelson, R.E.; LaFleur, J. The clinical epidemiology of male osteoporosis: A review of the recent literature. Clin. Epidemiol. 2015, 7, 65-76. 
9. Amelio, P.; Isaia, G.C. Male osteoporosis in the elderly. Int. J. Endocrinol. 2015, 2015, 8.

10. NIH Osteoporosis and Related Bone Diseases-National Resource Center. Osteoporosis in Men. Available online: https: / /www.bones.nih.gov/health-info/bone/osteoporosis/men (accessed on 12 March 2019).

11. Feng, X.; McDonald, J.M. Disorders of bone remodeling. Annu. Rev. Pathol. 2011, 6, 121-145. [CrossRef]

12. O'Brien, C.A.; Almeida, M. Basic biology of skeletal aging: Role of stress response pathways. J. Gerontol. 2013, 68, 1197-1208.

13. Giusti, A.; Bianchi, G. Treatment of primary osteoporosis in men. Clin. Interv. Aging 2015, 10, $105-115$. [PubMed]

14. Bliuc, D.; Alarkawi, D.; Nguyen, T.V.; Eisman, J.A.; Center, J.R. Risk of subsequent fractures and mortality in elderly women and men with fragility fractures with and without osteoporotic bone density: The dubbo osteoporosis epidemiology study. J. Bone Miner Res. 2015, 30, 637-646. [CrossRef] [PubMed]

15. Chin, K.Y.; Ima-Nirwana, S. The biological effects of tocotrienol on bone: A review on evidence from rodent models. Drug Des. Dev. Ther. 2015, 9, 2049-2061. [CrossRef] [PubMed]

16. Chin, K.-Y.; Ima-Nirwana, S. Vitamin e as an antiosteoporotic agent via receptor activator of nuclear factor kappa-b ligand signaling disruption: Current evidence and other potential research areas. Evid. Based Complement Altern. Med. 2012, 2012, 747020. [CrossRef] [PubMed]

17. Chin, K.-Y.; Mo, H.; Soelaiman, I.-N. A review of the possible mechanisms of action of tocotrienol-A potential antiosteoporotic agent. Curr. Drug Targets 2013, 14, 1533-1541. [CrossRef] [PubMed]

18. Ahsan, H.; Ahad, A.; Siddiqui, W.A. A review of characterization of tocotrienols from plant oils and foods. J. Chem. Biol. 2015, 8, 45-59. [CrossRef]

19. Aggarwal, B.; Sundaram, C.; Prasad, S.; Kannappan, R. Tocotrienols, the vitamin e of the 21st century: It's potential against cancer and other chronic diseases. Biochem. Pharmacol. 2010, 80, 1613-1631. [CrossRef] [PubMed]

20. Fairus, S.; Nor, R.M.; Cheng, H.M.; Sundram, K. Alpha-tocotrienol is the most abundant tocotrienol isomer circulated in plasma and lipoproteins after postprandial tocotrienol-rich vitamin e supplementation. Nutr. J. 2012, 11, 5. [CrossRef]

21. Hosomi, A.; Arita, M.; Sato, Y.; Kiyose, C.; Ueda, T.; Igarashi, O.; Arai, H.; Inoue, K. Affinity for alpha-tocopherol transfer protein as a determinant of the biological activities of vitamin e analogs. FEBS Lett. 1997, 409, 105-108. [CrossRef]

22. Shen, C.L.; Klein, A.; Chin, K.Y.; Mo, H.; Tsai, P.; Yang, R.S.; Chyu, M.C.; Ima-Nirwana, S. Tocotrienols for bone health: A translational approach. Ann. N. Y. Acad. Sci. 2017, 1401, 150-165. [CrossRef]

23. Muhammad, N.; Luke, D.A.; Shuid, A.N.; Mohamed, N.; Soelaiman, I.N. Two different isomers of vitamin e prevent bone loss in postmenopausal osteoporosis rat model. Evid. Based Complement Altern. Med. 2012, 2012, 161527. [CrossRef]

24. Muhammad, N.; Razali, S.; Shuid, A.N.; Mohamed, N.; Soelaiman, I.N. Membandingkan kesan antara fraksi-kaya tokotrienol, kalsium dan estrogen terhadap metabolisme tulang tikus terovariektomi. Sains Malays. 2013, 42, 1591-1597.

25. Soelaiman, I.N.; Ming, W.; Abu Bakar, R.; Hashnan, N.A.; Mohd Ali, H.; Mohamed, N.; Muhammad, N.; Shuid, A.N. Palm tocotrienol supplementation enhanced bone formation in oestrogen-deficient rats. Int. J. Endocrinol. 2012, 2012, 532862. [CrossRef]

26. Abdul-Majeed, S.; Mohamed, N.; Soelaiman, I.-N. Effects of tocotrienol and lovastatin combination on osteoblast and osteoclast activity in estrogen-deficient osteoporosis. Evid. Based Complement Altern. Med. 2012, 2012, 960742. [CrossRef]

27. Abdul-Majeed, S.; Mohamed, N.; Soelaiman, I.N. The use of delta-tocotrienol and lovastatin for anti-osteoporotic therapy. Life Sci. 2015, 125, 42-48. [CrossRef]

28. Chin, K.Y.; Abdul-Majeed, S.; Mohamed, N.; Ima-Nirwana, S. The effects of tocotrienol and lovastatin co-supplementation on bone dynamic histomorphometry and bone morphogenetic protein-2 expression in rats with estrogen deficiency. Nutrients 2017, 9, 143. [CrossRef]

29. Chin, K.Y.; Ima Nirwana, S. The effects of annatto-derived tocotrienol supplementation in osteoporosis induced by testosterone deficiency in rats. Clin. Interv. Aging 2014, 9, 1247-1259. [CrossRef]

30. Mohamad, N.V.; Ima-Nirwana, S.; Chin, K.Y. Effect of tocotrienol from bixa orellana (annatto) on bone microstructure, calcium content, and biomechanical strength in a model of male osteoporosis induced by buserelin. Drug Des. Dev. Ther. 2018, 12, 555-564. [CrossRef] 
31. Mohamad, N.V.; Soelaiman, I.N.; Chin, K.Y. Effects of tocotrienol from bixa orellana (annatto) on bone histomorphometry in a male osteoporosis model induced by buserelin. Biomed. Pharmacother. 2018, 103, 453-462. [CrossRef]

32. Wong, S.K.; Chin, K.Y.; Suhaimi, F.H.; Ahmad, F.; Ima-Nirwana, S. Exploring the potential of tocotrienol from bixa orellana as a single agent targeting metabolic syndrome and bone loss. Bone 2018, 116, 8-21. [CrossRef]

33. Wong, S.K.; Chin, K.-Y.; Suhaimi, F.H.; Ahmad, F.; Ima-Nirwana, S. The effects of palm tocotrienol on metabolic syndrome and bone loss in male rats induced by high-carbohydrate high-fat diet. J. Funct Foods 2018, 44, 246-254. [CrossRef]

34. Wong, S.K.; Chin, K.-Y.; Suhaimi, F.H.; Ahmad, F.; Jamil, N.A.; Ima-Nirwana, S. Osteoporosis is associated with metabolic syndrome induced by high-carbohydrate high-fat diet in a rat model. Biomed. Pharmacother. 2018, 98, 191-200. [CrossRef]

35. Ima Nirwana, S.; Kiftiah, A.; Zainal, A.; Norazlina, M.; Gapor, M.; Khalid, B.A.K. Palm vitamin e prevents osteoporosis in orchidectomised growing male rats. Nat. Prod. Sci. 2000, 6, 155-160.

36. Ima-Nirwana, S.; Fakhrurazi, H. Palm vitamin e protects bone against dexamethasone-induced osteoporosis in male rats. Med. J. 2002, 57, 133-141.

37. Ima Nirwana, S.; Suhaniza, S. Effects of tocopherols and tocotrienols on body composition and bone calcium content in adrenalectomized rats replaced with dexamethasone. J. Med. Food 2004, 7, 45-51. [CrossRef]

38. Zakaria, S.; Mat-Husain, S.Z.; Ying-Hwey, K.; Xin-Kai, K.; Mohd-Badawi, A.; Abd-Ghani, N.A.; Aziz, M.A.; Mohamed, N. Vitamin e improved bone strength and bone minerals in male rats given alcohol. Iran J. Basic Med. Sci. 2017, 20, 1360-1367.

39. Wong, S.; Chin, K.-Y.; Suhaimi, F.; Ahmad, F.; Ima-Nirwana, S. The effects of vitamin e from elaeis guineensis (oil palm) in a rat model of bone loss due to metabolic syndrome. Int. J. Environ. Res. Public Health 2018, 15, 1828. [CrossRef]

40. Chin, K.Y.; Abdul-Majeed, S.; Fozi, N.F.; Ima-Nirwana, S. Annatto tocotrienol improves indices of bone static histomorphometry in osteoporosis due to testosterone deficiency in rats. Nutrients 2014, 6, 4974-4983. [CrossRef]

41. Chin, K.Y.; Gengatharan, D.; Mohd Nasru, F.S.; Khairussam, R.A.; Ern, S.L.; Aminuddin, S.A.; Ima-Nirwana, S. The effects of annatto tocotrienol on bone biomechanical strength and bone calcium content in an animal model of osteoporosis due to testosterone deficiency. Nutrients 2016, 8, 808. [CrossRef]

42. Hermizi, H.; Faizah, O.; Ima-Nirwana, S.; Ahmad Nazrun, S.; Norazlina, M. Beneficial effects of tocotrienol and tocopherol on bone histomorphometric parameters in sprague-dawley male rats after nicotine cessation. Calcif. Tissue Int. 2009, 84, 65-74. [CrossRef]

43. Norazlina, M.; Hermizi, H.; Faizah, O.; Ima-Nirwana, S. Vitamin e reversed nicotine-induced toxic effects on bone biochemical markers in male rats. Arch. Med. Sci. 2010, 6, 505-512. [CrossRef]

44. Mehat, M.; Shuid, A.; Mohamed, N.; Muhammad, N.; Soelaiman, I. Beneficial effects of vitamin e isomer supplementation on static and dynamic bone histomorphometry parameters in normal male rats. J. Bone Miner Metab. 2010, 28, 503-509. [CrossRef]

45. Shuid, A.; Mehat, Z.; Mohamed, N.; Muhammad, N.; Soelaiman, I. Vitamin e exhibits bone anabolic actions in normal male rats. J. Bone Miner Metab. 2010, 28, 149-156. [CrossRef]

46. Maniam, S.; Mohamed, N.; Shuid, A.N.; Soelaiman, I.N. Palm tocotrienol exerted better antioxidant activities in bone than $\alpha$-tocopherol. Basic Clin. Pharmacol. Toxicol. 2008, 103, 55-60. [CrossRef]

47. Gordon, C.M.; Zemel, B.S.; Wren, T.A.; Leonard, M.B.; Bachrach, L.K.; Rauch, F.; Gilsanz, V.; Rosen, C.J.; Winer, K.K. The determinants of peak bone mass. J. Pediatr. 2017, 180, 261-269. [CrossRef]

48. Tennant, K.G.; Leonard, S.W.; Wong, C.P.; Iwaniec, U.T.; Turner, R.T.; Traber, M.G. High-dietary alpha-tocopherol or mixed tocotrienols have no effect on bone mass, density, or turnover in male rats during skeletal maturation. J. Med. Food 2017, 20, 700-708. [CrossRef]

49. Chin, K.Y.; Ima-Nirwana, S. The effects of alpha-tocopherol on bone: A double-edged sword? Nutrients 2014, 6, 1424-1441. [CrossRef]

50. Abd Manan, N.; Mohamed, N.; Shuid, A.N. Effects of low-dose versus high-dose gamma-tocotrienol on the bone cells exposed to the hydrogen peroxide-induced oxidative stress and apoptosis. Evid. Based Complement Altern. Med. 2012, 2012, 680834. [CrossRef]

51. Callaway, D.A.; Jiang, J.X. Reactive oxygen species and oxidative stress in osteoclastogenesis, skeletal aging and bone diseases. J. Bone Miner Metab. 2015, 33, 359-370. [CrossRef] 
52. Wang, X.; Chen, B.; Sun, J.; Jiang, Y.; Zhang, H.; Zhang, P.; Fei, B.; Xu, Y. Iron-induced oxidative stress stimulates osteoclast differentiation via nf-kappab signaling pathway in mouse model. Metabolism 2018, 83, 167-176. [CrossRef]

53. Li, D.Y.; Yu, J.C.; Xiao, L.; Miao, W.; Ji, K.; Wang, S.C.; Geng, Y.X. Autophagy attenuates the oxidative stress-induced apoptosis of mc3t3-e1 osteoblasts. Eur. Rev. Med. Pharmacol. Sci. 2017, 21, 5548-5556.

54. Mohamad, N.V.; Soelaiman, I.N.; Chin, K.Y. A concise review of testosterone and bone health. Clin. Interv. Aging 2016, 11, 1317-1324. [CrossRef]

55. Chin, K.Y.; Ima-Nirwana, S. Sex steroids and bone health status in men. Int. J. Endocrinol. 2012, $2012,208719$. [CrossRef]

56. Wu, X.; Zhang, M. Effects of androgen and progestin on the proliferation and differentiation of osteoblasts. Exp. Ther. Med. 2018, 16, 4722-4728. [CrossRef]

57. Almeida, M.; Han, L.; Ambrogini, E.; Bartell, S.M.; Manolagas, S.C. Oxidative stress stimulates apoptosis and activates nf-kappab in osteoblastic cells via a pkcbeta/p66shc signaling cascade: Counter regulation by estrogens or androgens. Mol. Endocrinol. 2010, 24, 2030-2037. [CrossRef]

58. Proell, V.; Xu, H.; Schuler, C.; Weber, K.; Hofbauer, L.C.; Erben, R.G. Orchiectomy upregulates free soluble rankl in bone marrow of aged rats. Bone 2009, 45, 677-681. [CrossRef]

59. Sinnesael, M.; Boonen, S.; Claessens, F.; Gielen, E.; Vanderschueren, D. Testosterone and the male skeleton: A dual mode of action. J. Osteoporos. 2011, 2011, 240328. [CrossRef]

60. Herrmann, B.L.; Saller, B.; Janssen, O.E.; Gocke, P.; Bockisch, A.; Sperling, H.; Mann, K.; Broecker, M. Impact of estrogen replacement therapy in a male with congenital aromatase deficiency caused by a novel mutation in the cyp19 gene. J. Clin. Endocrinol. Metab. 2002, 87, 5476-5484. [CrossRef]

61. Lanfranco, F.; Zirilli, L.; Baldi, M.; Pignatti, E.; Corneli, G.; Ghigo, E.; Aimaretti, G.; Carani, C.; Rochira, V. A novel mutation in the human aromatase gene: Insights on the relationship among serum estradiol, longitudinal growth and bone mineral density in an adult man under estrogen replacement treatment. Bone 2008, 43, 628-635. [CrossRef]

62. Morishima, A.; Grumbach, M.M.; Simpson, E.R.; Fisher, C.; Qin, K. Aromatase deficiency in male and female siblings caused by a novel mutation and the physiological role of estrogens. J. Clin. Endocrinol. Metab. 1995, 80, 3689-3698.

63. Smith, E.P.; Boyd, J.; Frank, G.R.; Takahashi, H.; Cohen, R.M.; Specker, B.; Williams, T.C.; Lubahn, D.B.; Korach, K.S. Estrogen resistance caused by a mutation in the estrogen-receptor gene in a man. N. Engl. J. Med. 1994, 331, 1056-1061. [CrossRef]

64. Dudek, P.; Kozakowski, J.; Zgliczyński, W. Late-onset hypogonadism. Prz Menopauzal. 2017, 16, 66-69. [CrossRef]

65. Harman, S.M.; Metter, E.J.; Tobin, J.D.; Pearson, J.; Blackman, M.R. Longitudinal effects of aging on serum total and free testosterone levels in healthy men. J. Clin. Endocrinol. Metab. 2001, 86, 724-731. [CrossRef]

66. Kim, H.J.; Koo, H.S.; Kim, Y.S.; Kim, M.J.; Kim, K.M.; Joo, N.S.; Haam, J.H. The association of testosterone, sex hormone-binding globulin, and insulin-like growth factor-1 with bone parameters in korean men aged 50 years or older. J. Bone Miner Metab. 2017, 35, 659-665. [CrossRef]

67. Chin, K.-Y.; Soelaiman, I.-N.; Naina Mohamed, I.; Shahar, S.; Teng, N.I.M.F.; Suhana Mohd Ramli, E.; Ahmad, F.; Aminuddin, A.; Zurinah Wan Ngah, W. Testosterone is associated with age-related changes in bone health status, muscle strength and body composition in men. Aging Male 2012, 15, 240-245. [CrossRef]

68. Mohamad, N.V.; Soelaiman, I.N.; Chin, K.Y. Effect of androgen deprivation therapy (adt) on bone health status in men with prostate cancer. Endocr. Metab. Immune Disord. Drug Targets 2017, 17, 276-284. [CrossRef]

69. Chin, K.-Y.; Soelaiman, I.N. The effects of orchidectomy and supraphysiological testosterone administration on trabecular bone structure and gene expression in rats. Aging Male 2015, 18, 60-66. [CrossRef]

70. Brogden, R.N.; Buckley, M.M.; Ward, A. Buserelin. A review of its pharmacodynamic and pharmacokinetic properties, and clinical profile. Drugs 1990, 39, 399-437. [CrossRef]

71. Mohamad, N.-V.; Zulkepli, M.A.A.C.; Theseira, K.M.; Zulkifli, N.; Shahrom, N.Q.N.A.M.R.; Jamil, N.A.; Soelaiman, I.-N.; Chin, K.-Y. Establishing an animal model of secondary osteoporosis by using a gonadotropin-releasing hormone agonist. Int. J. Med. Sci. 2018, 15, 300-308. [CrossRef]

72. Alberti, K.G.; Eckel, R.H.; Grundy, S.M.; Zimmet, P.Z.; Cleeman, J.I.; Donato, K.A.; Fruchart, J.C.; James, W.P.; Loria, C.M.; Smith, S.C., Jr. Harmonizing the metabolic syndrome: A joint interim statement of the international diabetes federation task force on epidemiology and prevention; national heart, lung, 
and blood institute; american heart association; world heart federation; international atherosclerosis society; and international association for the study of obesity. Circulation 2009, 120, 1640-1645.

73. Wong, S.K.; Chin, K.-Y.; Suhaimi, F.; Ahmad, F.; Ima-Nirwana, S. The relationship between metabolic syndrome and osteoporosis: A review. Nutrients 2016, 8, 347. [CrossRef]

74. Abbasi, M.; Farzam, S.A.; Mamaghani, Z.; Yazdi, Z. Relationship between metabolic syndrome and its components with bone densitometry in postmenopausal women. Diabetes Metab. Syndr. 2017, 11, S73-S76. [CrossRef]

75. Alhazidou, E.; Pergialiotis, V.; Panagopoulos, P.; Chrelias, C.; Hatziagelaki, E.; Papantoniou, N.; Trakakis, E. The impact of the metabolic syndrome on bone mass density: A prospective case control study. Horm. Mol. Biol. Clin. Investig. 2017, 33. [CrossRef]

76. Loke, S.S.; Chang, H.W.; Li, W.C. Association between metabolic syndrome and bone mineral density in a taiwanese elderly population. J. Bone Miner Metab. 2018, 36, 200-208. [CrossRef]

77. Cao, J.J. Effects of obesity on bone metabolism. J. Orthop. Surg. Res. 2011, 6, 30. [CrossRef]

78. Caudarella, R.; Vescini, F.; Rizzoli, E.; Francucci, C.M. Salt intake, hypertension, and osteoporosis. J. Endocrinol. Investig. 2009, 32, 15-20.

79. Liu, J.; Mao, J.; Jiang, Y.; Xia, L.; Mao, L.; Wu, Y.; Ma, P.; Fang, B. Ages induce apoptosis in rat osteoblast cells by activating the caspase- 3 signaling pathway under a high-glucose environment in vitro. Appl. Biochem. Biotechnol. 2016, 178, 1015-1027. [CrossRef]

80. Chen, Y.; Hu, Y.; Yang, L.; Zhou, J.; Tang, Y.; Zheng, L.; Qin, P. Runx2 alleviates high glucose-suppressed osteogenic differentiation via pi3k/akt/gsk3beta/beta-catenin pathway. Cell Biol Int. 2017, 41, 822-832. [CrossRef]

81. Cai, Z.Y.; Yang, B.; Shi, Y.X.; Zhang, W.L.; Liu, F.; Zhao, W.; Yang, M.W. High glucose downregulates the effects of autophagy on osteoclastogenesis via the ampk/mtor/ulk1 pathway. Biochem. Biophys. Res. Commun. 2018, 503, 428-435. [CrossRef]

82. Brodeur, M.R.; Brissette, L.; Falstrault, L.; Ouellet, P.; Moreau, R. Influence of oxidized low-density lipoproteins (ldl) on the viability of osteoblastic cells. Free Radic. Biol. Med. 2008, 44, 506-517. [CrossRef]

83. Maziere, C.; Savitsky, V.; Galmiche, A.; Gomila, C.; Massy, Z.; Maziere, J.C. Oxidized low density lipoprotein inhibits phosphate signaling and phosphate-induced mineralization in osteoblasts. Involvement of oxidative stress. Biochim. Biophys. Acta 2010, 1802, 1013-1019. [CrossRef]

84. Hou, C.; Luan, L.; Ren, C. Oxidized low-density lipoprotein promotes osteoclast differentiation from cd68 positive mononuclear cells by regulating hmgb1 release. Biochem. Biophys. Res Commun. 2018, 495, 1356-1362. [CrossRef]

85. Wong, S.K.; Chin, K.-Y.; Suhaimi, F.H.; Ahmad, F.; Ima-Nirwana, S. Effects of metabolic syndrome on bone mineral density, histomorphometry and remodelling markers in male rats. PLoS ONE 2018, 13, e0192416. [CrossRef]

86. Wu, Z.-J.; Zhao, P.; Liu, B.; Yuan, Z.-C. Effect of cigarette smoking on risk of hip fracture in men: A meta-analysis of 14 prospective cohort studies. PLoS ONE 2016, 11, e0168990. [CrossRef]

87. Lee, J.H.; Hong, A.R.; Kim, J.H.; Kim, K.M.; Koo, B.K.; Shin, C.S.; Kim, S.W. Amount of smoking, pulmonary function, and bone mineral density in middle-aged korean men: Knhanes 2008-2011. J. Bone Miner Metab. 2018, 36, 95-102. [CrossRef]

88. Kim, B.S.; Kim, S.J.; Kim, H.J.; Lee, S.J.; Park, Y.J.; Lee, J.; You, H.K. Effects of nicotine on proliferation and osteoblast differentiation in human alveolar bone marrow-derived mesenchymal stem cells. Life Sci. 2012, 90, 109-115. [CrossRef]

89. Liang, D.; Wang, K.J.; Tang, Z.Q.; Liu, R.H.; Zeng, F.; Cheng, M.Y.; Lian, Q.S.; Wu, H.K. Effects of nicotine on the metabolism and gene expression profile of spraguedawley rat primary osteoblasts. Mol. Med. Rep. 2018, $17,8269-8281$.

90. Kallala, R.; Barrow, J.; Graham, S.M.; Kanakaris, N.; Giannoudis, P.V. The in vitro and in vivo effects of nicotine on bone, bone cells and fracture repair. Expert Opin. Drug Saf. 2013, 12, 209-233. [CrossRef]

91. Hapidin, H.; Othman, F.; Soelaiman, I.N.; Shuid, A.N.; Luke, D.A.; Mohamed, N. Negative effects of nicotine on bone-resorbing cytokines and bone histomorphometric parameters in male rats. J. Bone Miner Metab. 2007, 25, 93-98. [CrossRef] 
92. Hapidin, H.; Othman, F.; Soelaiman, I.N.; Shuid, A.N.; Mohamed, N. Effects of nicotine administration and nicotine cessation on bone histomorphometry and bone biomarkers in sprague-dawley male rats. Calcif. Tissue Int. 2011, 88, 41-47. [CrossRef]

93. Abukhadir, S.S.A.; Mohamed, N.; Makpol, S.; Muhammad, N. Effects of palm vitamin e on bone-formation-related gene expression in nicotine-treated rats. Evid. Based Complement Altern. Med. 2012, 2012, 656025. [CrossRef]

94. Cho, Y.; Choi, S.; Kim, K.; Lee, G.; Park, S.M. Association between alcohol consumption and bone mineral density in elderly korean men and women. Arch. Osteoporos 2018, 13, 46. [CrossRef]

95. Luo, Z.; Liu, Y.; Liu, Y.; Chen, H.; Shi, S.; Liu, Y. Cellular and molecular mechanisms of alcohol-induced osteopenia. Cell Mol. Life Sci. 2017, 74, 4443-4453. [CrossRef]

96. Maneesh, M.; Dutta, S.; Chakrabarti, A.; Vasudevan, D.M. Alcohol abuse-duration dependent decrease in plasma testosterone and antioxidants in males. Indian J. Physiol. Pharmacol. 2006, 50, 291-296.

97. Perrien, D.S.; Brown, E.C.; Fletcher, T.W.; Irby, D.J.; Aronson, J.; Gao, G.G.; Skinner, R.A.; Hogue, W.R.; Feige, U.; Suva, L.J.; et al. Interleukin-1 and tumor necrosis factor antagonists attenuate ethanol-induced inhibition of bone formation in a rat model of distraction osteogenesis. J. Pharmacol. Exp. Ther. 2002, 303, 904-908. [CrossRef]

98. Liu, Y.; Kou, X.; Chen, C.; Yu, W.; Su, Y.; Kim, Y.; Shi, S.; Liu, Y. Chronic high dose alcohol induces osteopenia via activation of mtor signaling in bone marrow mesenchymal stem cells. Stem. Cells 2016, 34, 2157-2168. [CrossRef]

99. Gonzalez-Reimers, E.; Martin-Gonzalez, C.; de la Vega-Prieto, M.J.; Pelazas-Gonzalez, R.; FernandezRodriguez, C.; Lopez-Prieto, J.; Alvisa-Negrin, J.; Santolaria-Fernandez, F. Serum sclerostin in alcoholics: A pilot study. Alcohol. Alcohol. 2013, 48, 278-282. [CrossRef]

100. Whittier, X.; Saag, K.G. Glucocorticoid-induced osteoporosis. Rheum. Dis. Clin. N. Am. 2016, 42, 177-189, x. [CrossRef]

101. Mak, W.; Shao, X.; Dunstan, C.R.; Seibel, M.J.; Zhou, H. Biphasic glucocorticoid-dependent regulation of wnt expression and its inhibitors in mature osteoblastic cells. Calcif. Tissue Int. 2009, 85, 538-545. [CrossRef]

102. Gifre, L.; Ruiz-Gaspa, S.; Monegal, A.; Nomdedeu, B.; Filella, X.; Guanabens, N.; Peris, P. Effect of glucocorticoid treatment on wnt signalling antagonists (sclerostin and dkk-1) and their relationship with bone turnover. Bone 2013, 57, 272-276. [CrossRef]

103. Smith, E.; Frenkel, B. Glucocorticoids inhibit the transcriptional activity of lef/tcf in differentiating osteoblasts in a glycogen synthase kinase-3ß-dependent and -independent manner. J. Biol. Chem. 2005, 280, 2388-2394. [CrossRef]

104. Koromila, T.; Baniwal, S.K.; Song, Y.S.; Martin, A.; Xiong, J.; Frenkel, B. Glucocorticoids antagonize runx2 during osteoblast differentiation in cultures of st2 pluripotent mesenchymal cells. J. Cell Biochem. 2014, 115, 27-33. [CrossRef]

105. Piemontese, M.; Xiong, J.; Fujiwara, Y.; Thostenson, J.D.; O’Brien, C.A. Cortical bone loss caused by glucocorticoid excess requires rankl production by osteocytes and is associated with reduced opg expression in mice. Am. J. Physiol. Endocrinol. Metab. 2016, 311, E587-E593. [CrossRef]

106. Mac, A.M.; White, R.H.; Chipps, B.E. Reduction of serum testosterone levels during chronic glucocorticoid therapy. Ann. Int. Med. 1986, 104, 648-651.

107. Gennari, C. Differential effect of glucocorticoids on calcium absorption and bone mass. Rheumatology 1993, 32, 11-14. [CrossRef]

108. Prummel, M.F.; Wiersinga, W.M.; Oosting, H.; Endert, E. The effect of long-term prednisone treatment on growth hormone and insulin-like growth factor-i. J. Endocrinol. Investig. 1996, 19, 620-623. [CrossRef]

109. Domazetovic, V.; Marcucci, G.; Iantomasi, T.; Brandi, M.L.; Vincenzini, M.T. Oxidative stress in bone remodeling: Role of antioxidants. Clin. Cases Miner Bone Metab. 2017, 14, 209-216. [CrossRef]

110. Karademirci, M.; Kutlu, R.; Kilinc, I. Relationship between smoking and total antioxidant status, total oxidant status, oxidative stress index, Vit C, Vit E. Clin. Respir J. 2018, 12, 2006-2012. [CrossRef]

111. Budzynski, J.; Ziolkowski, M.; Klopocka, M.; Czarnecki, D. Oxidoreductive homeostasis in alcohol-dependent male patients and the risk of alcohol drinking relapse in a 6-month follow-up. Alcohol 2016, 50, 57-64. [CrossRef]

112. Rani, V.; Deep, G.; Singh, R.K.; Palle, K.; Yadav, U.C. Oxidative stress and metabolic disorders: Pathogenesis and therapeutic strategies. Life Sci. 2016, 148, 183-193. [CrossRef] 
113. Bonaccorsi, G.; Piva, I.; Greco, P.; Cervellati, C. Oxidative stress as a possible pathogenic cofactor of post-menopausal osteoporosis: Existing evidence in support of the axis oestrogen deficiency-redox imbalance-bone loss. Indian J. Med. Res. 2018, 147, 341-351.

114. Makary, S.; Abdo, M.; Fekry, E. Oxidative stress burden inhibits spermatogenesis in adult male rats: Testosterone protective effect. Can. J. Physiol. Pharmacol. 2018, 96, 372-381. [CrossRef]

115. Son, S.W.; Lee, J.S.; Kim, H.G.; Kim, D.W.; Ahn, Y.C.; Son, C.G. Testosterone depletion increases the susceptibility of brain tissue to oxidative damage in a restraint stress mouse model. J. Neurochem. 2016, 136, 106-117. [CrossRef]

116. Eleawa, S.M.; Sakr, H.F.; Hussein, A.M.; Assiri, A.S.; Bayoumy, N.M.; Alkhateeb, M. Effect of testosterone replacement therapy on cardiac performance and oxidative stress in orchidectomized rats. Acta Physiol. 2013, 209, 136-147. [CrossRef]

117. Skogastierna, C.; Hotzen, M.; Rane, A.; Ekstrom, L. A supraphysiological dose of testosterone induces nitric oxide production and oxidative stress. Eur. J. Prev. Cardiol. 2014, 21, 1049-1054. [CrossRef]

118. Contini, M.D.; Millen, N.; Gonzalez, M.; Benmelej, A.; Fabro, A.; Mahieu, S. Orchiectomy attenuates oxidative stress induced by aluminum in rats. Toxicol. Ind. Health 2016, 32, 1515-1526. [CrossRef]

119. Tothova, L.; Celec, P.; Ostatnikova, D.; Okuliarova, M.; Zeman, M.; Hodosy, J. Effect of exogenous testosterone on oxidative status of the testes in adult male rats. Andrologia 2013, 45, 417-423. [CrossRef]

120. Nizar, A.; Ahmad Nazrun, S.; Norazlina, M.; Norliza, M.; Ima Nirwana, S. Low dose of tocotrienols protects osteoblasts against oxidative stress. Clin. Ter. 2011, 162, 533-538.

121. Takano, H.; Momota, Y.; Kani, K.; Aota, K.; Yamamura, Y.; Yamanoi, T.; Azuma, M. Gamma-tocotrienol prevents 5-fu-induced reactive oxygen species production in human oral keratinocytes through the stabilization of 5-fu-induced activation of nrf2. Int. J. Oncol. 2015, 46, 1453-1460. [CrossRef]

122. Liu, T.; Zhang, L.; Joo, D.; Sun, S.-C. Nf-kb signaling in inflammation. Signal. Transduct Target Ther. 2017, 2, 17023. [CrossRef]

123. Oeckinghaus, A.; Ghosh, S. The nf-kappab family of transcription factors and its regulation. Cold Spring Harb. Perspect Biol. 2009, 1, a000034. [CrossRef]

124. Otero, J.E.; Dai, S.; Foglia, D.; Alhawagri, M.; Vacher, J.; Pasparakis, M.; Abu-Amer, Y. Defective osteoclastogenesis by ikkbeta-null precursors is a result of receptor activator of NF-kB ligand (rankl)-induced jnk-dependent apoptosis and impaired differentiation. J. Biol. Chem. 2008, 283, 24546-24553. [CrossRef]

125. Ruocco, M.G.; Maeda, S.; Park, J.M.; Lawrence, T.; Hsu, L.C.; Cao, Y.; Schett, G.; Wagner, E.F.; Karin, M. Ikb kinase $i k k \beta$, but not $i k k \alpha$, is a critical mediator of osteoclast survival and is required for inflammation-induced bone loss. J. Exp. Med. 2005, 201, 1677-1687. [CrossRef]

126. Yao, Z.; Xing, L.; Boyce, B.F. NF-kB p100 limits tnf-induced bone resorption in mice by a traf3-dependent mechanism. J. Clin. Investig. 2009, 119, 3024-3034. [CrossRef]

127. Xiu, Y.; Xu, H.; Zhao, C.; Li, J.; Morita, Y.; Yao, Z.; Xing, L.; Boyce, B.F. Chloroquine reduces osteoclastogenesis in murine osteoporosis by preventing TRAF3 degradation. J. Clin. Investig. 2014, 124, 297-310. [CrossRef]

128. Chang, J.; Wang, Z.; Tang, E.; Fan, Z.; McCauley, L.; Franceschi, R.; Guan, K.; Krebsbach, P.H.; Wang, C.Y. Inhibition of osteoblastic bone formation by NF-kB. Nat. Med. 2009, 15, 682-689. [CrossRef]

129. Loganathan, R.; Selvaduray, K.R.; Nesaretnam, K.; Radhakrishnan, A.K. Tocotrienols promote apoptosis in human breast cancer cells by inducing poly(adp-ribose) polymerase cleavage and inhibiting NF- $\mathrm{kB}$ activity. Cell Prolif. 2013, 46, 203-213. [CrossRef]

130. Wang, Y.; Jiang, Q. Gamma-tocotrienol inhibits lipopolysaccharide-induced interlukin-6 and granulocyte colony-stimulating factor by suppressing c/ebpßand NF-kB in macrophages. J. Nutr. Biochem. 2013, 24, 1146-1152. [CrossRef]

131. Sun, W.G.; Song, R.P.; Wang, Y.; Ge, S.; Zhang, Y.H.; Wang, H.X.; Liu, J.; Liu, L.X. R-tocotrienol inhibits cell proliferation of human gastric cancer by regulating NF-kB activity. J. Agric. Food Chem. 2018.

132. Husain, K.; Francois, R.A.; Yamauchi, T.; Perez, M.; Sebti, S.M.; Malafa, M.P. Vitamin E $\delta$-tocotrienol augments the antitumor activity of gemcitabine and suppresses constitutive NF-kB activation in pancreatic cancer. Mol. Cancer Ther. 2011, 10, 2363-2372. [CrossRef]

133. Ahn, K.S.; Sethi, G.; Krishnan, K.; Aggarwal, B.B. Gamma-tocotrienol inhibits NF-кB signaling pathway through inhibition of receptor-interacting protein and TAK1 leading to suppression of antiapoptotic gene products and potentiation of apoptosis. J. Biol. Chem. 2007, 282, 809-820. [CrossRef] 
134. Ahmad, N.S.; Khalid, B.A.K.; Luke, D.A.; Ima Nirwana, S. Tocotrienol offers better protection than tocopherol from free radical-induced damage of rat bone. Clin. Exp. Pharmacol. Physiol. 2005, 32, 761-770. [CrossRef]

135. Brooks, R.; Kalia, P.; Ireland, D.; Beeton, C.; Rushton, N. Direct inhibition of osteoclast formation and activity by the vitamin E isomer $\gamma$-tocotrienol. Int. J. Vitam Nutr. Res. 2011, 81, 358-367. [CrossRef]

136. Mo, H.; Yeganehjoo, H.; Shah, A.; Mo, W.K.; Soelaiman, I.N.; Shen, C.-L. Mevalonate-suppressive dietary isoprenoids for bone health. J. Nutr. Biochem. 2012, 23, 1543-1551. [CrossRef]

137. Wan Hasan, W.N.; Chin, K.Y.; Jolly, J.J.; Abd Ghafar, N.; Soelaiman, I.N. Identifying potential therapeutics for osteoporosis by exploiting the relationship between mevalonate pathway and bone metabolism. Endocr. Metab. Immune Disord Drug Targets 2018, 18, 450-457. [CrossRef]

138. Takase, H.; Yano, S.; Yamaguchi, T.; Kanazawa, I.; Hayashi, K.; Yamamoto, M.; Yamauchi, M.; Sugimoto, T. Parathyroid hormone upregulates BMP-2 mrna expression through mevalonate kinase and rho kinase inhibition in osteoblastic mc3t3-e1 cells. Horm. Metab Res. 2009, 41, 861-865. [CrossRef]

139. Itzstein, C.; Coxon, F.P.; Rogers, M.J. The regulation of osteoclast function and bone resorption by small gtpases. Small GTPases 2011, 2, 117-130. [CrossRef]

140. Drake, M.T.; Clarke, B.L.; Khosla, S. Bisphosphonates: Mechanism of action and role in clinical practice. Mayo Clin. Proc. 2008, 83, 1032-1045. [CrossRef]

141. Abdul-Majeed, S.; Mohamed, N.; Soelaiman, I. A review on the use of statins and tocotrienols, individually or in combination for the treatment of osteoporosis. Curr. Drug Targets 2013, 14, 1579-1590. [CrossRef]

142. An, T.; Hao, J.; Sun, S.; Li, R.; Yang, M.; Cheng, G.; Zou, M. Efficacy of statins for osteoporosis: A systematic review and meta-analysis. Osteoporos Int. 2017, 28, 47-57. [CrossRef]

143. Parker, R.A.; Pearce, B.C.; Clark, R.W.; Gordon, D.A.; Wright, J.J. Tocotrienols regulate cholesterol production in mammalian cells by post-transcriptional suppression of 3-hydroxy-3-methylglutaryl-coenzyme a reductase. J. Biol. Chem. 1993, 268, 11230-11238.

144. Yeganehjoo, H.; DeBose-Boyd, R.; McFarlin, B.K.; Mo, H. Synergistic impact of d-delta-tocotrienol and geranylgeraniol on the growth and hmg coa reductase of human du145 prostate carcinoma cells. Nutr. Cancer 2017, 69, 682-691. [CrossRef]

145. Chen, C.C.; Liu, T.Y.; Huang, S.P.; Ho, C.T.; Huang, T.C. Differentiation and apoptosis induction by lovastatin and gamma-tocotrienol in hl-60 cells via ras/erk/NF- $\mathrm{B}$ and ras/akt/NF- $\mathrm{B}$ signaling dependent down-regulation of glyoxalase 1 and hmg-coa reductase. Cell Signal. 2015, 27, 2182-2190. [CrossRef]

146. Yang, Z.; Xiao, H.; Jin, H.; Koo, P.T.; Tsang, D.J.; Yang, C.S. Synergistic actions of atorvastatin with gamma-tocotrienol and celecoxib against human colon cancer ht29 and hct116 cells. Int. J. Cancer 2010, 126, 852-863.

147. Yamasaki, M.; Nishimura, M.; Sakakibara, Y.; Suiko, M.; Morishita, K.; Nishiyama, K. $\delta$-tocotrienol induces apoptotic cell death via depletion of intracellular squalene in ed 40515 cells. Food Funct 2014, 5, 2842-2849. [CrossRef]

148. Deng, L.; Ding, Y.; Peng, Y.; Wu, Y.; Fan, J.; Li, W.; Yang, R.; Yang, M.; Fu, Q. $\Gamma$-tocotrienol protects against ovariectomy-induced bone loss via mevalonate pathway as hmg-coa reductase inhibitor. Bone 2014, 67, 200-207. [CrossRef]

149. Shen, C.-L.; Wang, S.; Yang, S.; Tomison, M.D.; Abbasi, M.; Hao, L.; Scott, S.; Khan, M.S.; Romero, A.W.; Felton, C.K.; et al. A 12-week evaluation of annatto tocotrienol supplementation for postmenopausal women: Safety, quality of life, body composition, physical activity, and nutrient intake. BMC Complement. Altern. Med. 2018, 18, 198. [CrossRef]

150. Shen, C.L.; Yang, S.; Tomison, M.D.; Romero, A.W.; Felton, C.K.; Mo, H. Tocotrienol supplementation suppressed bone resorption and oxidative stress in postmenopausal osteopenic women: A 12-week randomized double-blinded placebo-controlled trial. Osteoporos Int. 2018, 29, 881-891. [CrossRef]

151. Ima-Nirwana, S.; Nurshazwani, Y.; Nazrun, A.S.; Norliza, M.; Norazlina, M. Subacute and subchronic toxicity studies of palm vitamin E in mice. J. Pharmacol. Toxicol. 2011, 6, 166-173. [CrossRef]

152. Deng, L.; Peng, Y.; Wu, Y.; Yang, M.; Ding, Y.; Chen, Q.; Fu, Q. Tissue distribution of emulsified $\gamma$-tocotrienol and its long-term biological effects after subcutaneous administration. Lipids Health Dis. 2014, 13, 66. [CrossRef]

153. Alqahtani, S.; Alayoubi, A.; Nazzal, S.; Sylvester, P.W.; Kaddoumi, A. Enhanced solubility and oral bioavailability of gamma-tocotrienol using a self-emulsifying drug delivery system (sedds). Lipids 2014, 49, 819-829. [CrossRef] 
154. Maniam, G.; Mai, C.-W.; Zulkefeli, M.; Dufès, C.; Tan, D.M.-Y.; Fu, J.-Y. Challenges and opportunities of nanotechnology as delivery platform for tocotrienols in cancer therapy. Front. Pharmacol. 2018, 9. [CrossRef]

155. Tan, B.; Llobrera, J. Annatto Extract Compositions Including Tocotrienols and Tocopherols and Methods of Use. Patent WO2005009135A1, 3 February 2005.

156. Lane, R.H. Compositions and Methods for Treating and Preventing Bone Diseases Using Tocotrienols. Patent WO2000002553A1, 20 January 2000.

157. Cheng, H.S.; Ton, S.H.; Tan, J.B.L.; Abdul Kadir, K. The ameliorative effects of a tocotrienol-rich fraction on the age-rage axis and hypertension in high-fat-diet-fed rats with metabolic syndrome. Nutrients 2017, 9, 984. [CrossRef]

158. Wong, W.Y.; Ward, L.C.; Fong, C.W.; Yap, W.N.; Brown, L. Anti-inflammatory $\gamma$ - and $\delta$-tocotrienols improve cardiovascular, liver and metabolic function in diet-induced obese rats. Eur. J. Nutr. 2017, 56, 133-150. [CrossRef]

159. Chin, K.Y.; Tay, S.S. A review on the relationship between tocotrienol and alzheimer disease. Nutrients 2018, 10, 881. [CrossRef]

160. Haleagrahara, N.; Swaminathan, M.; Chakravarthi, S.; Radhakrishnan, A. Therapeutic efficacy of vitamin E delta-tocotrienol in collagen-induced rat model of arthritis. BioMed Res. Int. 2014, 2014, 539540. [CrossRef]

161. Radhakrishnan, A.; Tudawe, D.; Chakravarthi, S.; Chiew, G.S.; Haleagrahara, N. Effect of gamma-tocotrienol in counteracting oxidative stress and joint damage in collagen-induced arthritis in rats. Exp. Ther. Med. 2014, 7, 1408-1414. [CrossRef]

162. Lim, J.J.; Ngah, W.Z.; Mouly, V.; Abdul Karim, N. Reversal of myoblast aging by tocotrienol rich fraction posttreatment. Oxid. Med. Cell Longev. 2013, 2013, 978101. [CrossRef]

163. Khor, S.C.; Razak, A.M.; Wan Ngah, W.Z.; Mohd Yusof, Y.A.; Abdul Karim, N.; Makpol, S. The tocotrienol-rich fraction is superior to tocopherol in promoting myogenic differentiation in the prevention of replicative senescence of myoblasts. PLoS ONE 2016, 11, e0149265. [CrossRef]

164. Friedman, S.M.; Mendelson, D.A. Epidemiology of fragility fractures. Clin. Geriatr. Med. 2014, 30, $175-181$. [CrossRef] 